\title{
EFFECT OF CHANGE OF TEMPERATURE UPON THE VIABILITY OF A THERMOPHILIC BACTERIUM*
}

\author{
JUN HIRANO, YOSHIHIKO MUTOH, MIZUHO KITAMURA, SHOHGO ASAI, \\ ISAMU NAKAJIMA and ATUSI TAKAMIYA \\ Laboratory of Biological Chemistry, Tokyo Institute of Technology \\ Received for publication, 28 June, 1958
}

\section{INTRODUCTION}

Regarding the nature of thermophilism of temperature-tolerant organism, Allen (1), in 1950, proposed a hypothesis which might be referred to as a dynamic theory of thermophilism. She maintained that the thermophilic organisms do not differ very much from ordinary mesophilic organisms in the thermolability of their enzymes, the essential difference lying in the rapidity of enzyme synthesis occurring in compensation of the enzymes destructed by heat.

Using a thermophilic bacterium isolated from compost, we carried out quantitative investigations on the growth, viability, and respiration of the bacterial cells at different temperatures, as well as their responses to the change of temperature, and some new phenomena were observed, which could hardly be interpreted by such a simple theory as proposed by Allen. Described herein are the experimental results which revealed a new aspect of the thermophilic nature of temperature-tolerant organisms.

\section{EXPERIMENTAL}

\section{Test organism:}

A species of thermophilic bacterium which could grow at extremely high temperatures (over $70^{\circ} \mathrm{C}$ ) was isolated from compost in the garden of this Institute. It was found to be a spore-forming, strict aerobic and gram-positive Bacillus.**

\section{Culture media:}

Peptone medium:

Peptone (Kyokuto Pharm. Co.) .................... 1.0 2.0\%

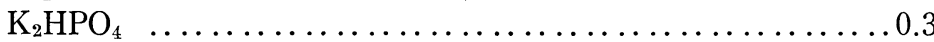

* Aided in part by a Scientific Research Grant from the Ministry of Education.

** A detailed report on the identification of this organism will be published elsewhere. 


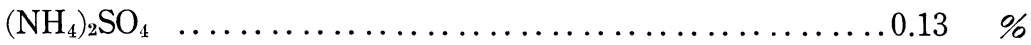

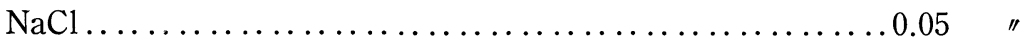

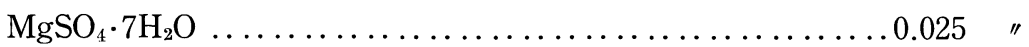

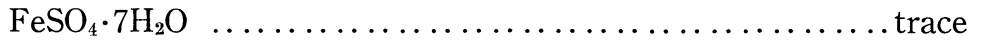

The $\mathrm{pH}$ value of the medium was adjusted to $7.0 \sim 7.2$ with $\mathrm{KOH}$ or $\mathrm{HCl}$. Synthetic medium:

Sucrose $\ldots \ldots \ldots \ldots \ldots 1.33 \%$; $i$-Inositol $\ldots \ldots \ldots \ldots \ldots 20 \times 10^{-6} \%$

Glutamic acid .........0.07 "; Thiamine ................... "

Tyrosine-HCl..........0.0053"; Niacin............10× " "

Alanine ............. "; Ca.pantothenate ......10× " "

Serine .............. 0.02 "; Adermin.................... "

Cystine- $\mathrm{HCl} \ldots \ldots \ldots \ldots .0 .02$ " ; Riboflavin ............10× " "

Arginine .............0.02 "; Choline ............10× " "

Minerals ............twice the amount as in the peptone medium.

Each component was sterilized separately in a concentrated solution and later mixed aseptically. The $\mathrm{pH}$ value was adjusted to $7.0 \sim 7.2$ by controlling $\mathrm{pH}$ of the cystine solution.

\section{Culture method:}

About $0.01 \mathrm{ml}$ of a 14 18-hour old static culture was inoculated into $9 \mathrm{ml}$ of fresh medium, which was placed in a $20-\mathrm{ml}$ test tube (straight or L-shaped). During the culture the tubes were constantly rotated or shaken in a water bath of a given temperature. When strict control of the inoculum was necessary, the inoculum was taken from a shaken culture which had been grown up to the first stage of the stationary phase, i.e., the stage in which the population density attained the level of $10^{8} \mathrm{cells} / \mathrm{ml}$.

Determination of cell concentration:

1) Turbidity. The turbidity of the culture was determined every 20 minutes, using for comparison a series of standard turbidity tubes, which were prepared by mixing $1 \mathrm{ml}$ of $4 \mathrm{~N} \mathrm{H}_{2} \mathrm{SO}_{4}, 0.5 \mathrm{ml}$ of $N / 3 \mathrm{BaCl}_{2}$, and $8.5 \mathrm{ml}$ of distilled water and diluting the mixture successively 1.5/1.0 times.

2) Total count. The total cell number was counted by direct microscopic observation using a Petroff-Hausser counting chamber. The values obtained by this method corresponded linearly to the turbidity within the practical range of bacterial concentration.

3) Viable count. Viable counting was effected in two ways: by the dilution method of the five-tube system (2) and, by the "lag time method" which will be described later in detail. In the dilution method $1 \mathrm{ml}$ of the test culture was mixed with $9 \mathrm{ml}$ of fresh medium, then $1 \mathrm{ml}$ of the mixture was again mixed with $9 \mathrm{ml}$ of fresh medium, and further dilution was continued successively in the same manner. Five parallel aliquots of $1 \mathrm{ml}$ taken from the mixture at appropriate dilution steps were poured into the fresh media in test tubes. After incubating the test tubes at $65^{\circ} \mathrm{C}$ for 3 to 18 hours, the number of the tubes which became turbid was observed, and the 
most probable viable cell concentration in the original test culture was calculated from the result. It was found that, in order to obtain the true values of viable counts, the sub-cultures had to be kept within the favourable temperature range during the whole procedure and the dilution process had to be performed as fast as possible. In practice, the whole procedure of dilution followed by the transference to sub-cultures was performed in a water bath of $65^{\circ} \mathrm{C}$, and completed within 10 minutes. The necessity of such rigid controls of time and temperature as these will be explained later.

\section{Measurement of respiration:}

Respiration rate was measured using a Barcroft manometer, which was installed in an air thermostat of a given temperature (3). The organisms used were those which had been grown at $65^{\circ} \mathrm{C}$ in the peptone medium, centrifuged down at a later stage of the logarithmic phase, and suspended in $0.5 \% \mathrm{NaCl}$ solution after being washed twice with the same solution. The substrate was composed of fresh peptone medium mixed with phosphate buffer of $\mathrm{pH} 7.0$.

\section{RESULTS}

\section{Growth and Viability at Different Temperatures.}

The range of temperature permitting growth of this organism was above $35^{\circ} \mathrm{C}$ and below $72^{\circ} \mathrm{C}$, the optimum being about $65^{\circ} \mathrm{C}$. In Figs. 1,2 and 3 are presented three representative data showing the change with time of total and viable counts at $75^{\circ} \mathrm{C}$, $65^{\circ} \mathrm{C}$ and $30^{\circ} \mathrm{C}$. Curves of viable counts obtained at various temperatures are summarized in Fig. 4.

From $75^{\circ} \mathrm{C}$ upwards, the viable population decreased almost instantly to $10^{\circ} \sim 10^{1}$ cells $/ \mathrm{ml}$, and later remained constant on the same level. In suspensions of the organisms kept in a Koch steam sterilizer at $99.8^{\circ} \mathrm{C}$, viable cells were detected for 5 hours but could not be detected after 10 hours. In a sub-optimal but proliferative temperature range $\left(35^{\circ} \mathrm{C} \sim\right.$

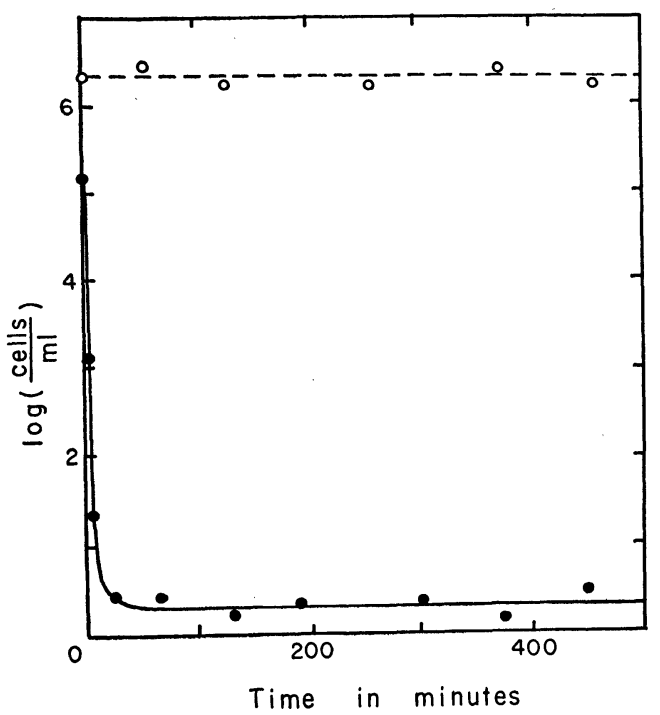

Fig. 1. Change with time of total and viable counts at $75^{\circ} \mathrm{C}$ in peptone medium. $\bigcirc=$ total count: $\quad=$ viable count. Cells died almost completely within 3 minutes after exposure to $75^{\circ} \mathrm{C}$. 


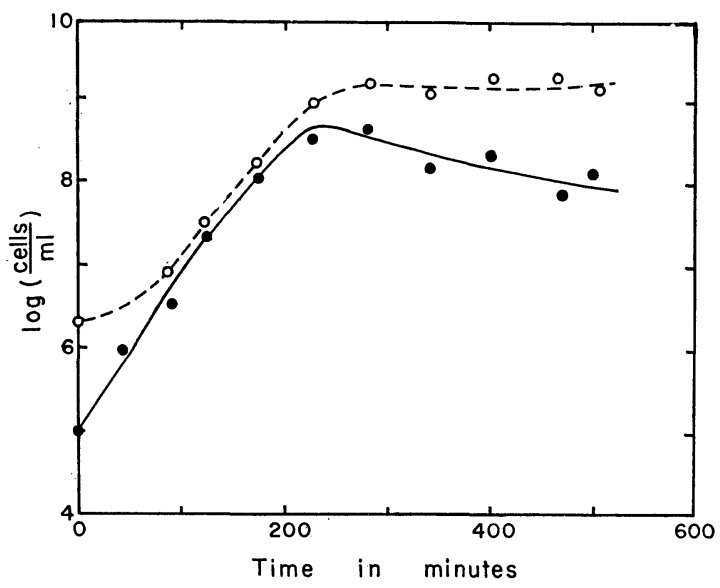

Fig. 2. Change with time of total and viable counts at $65^{\circ} \mathrm{C}$ in peptone medium.

$\bigcirc=$ total count: $\quad=$ viable count. Increase of viable count occurred within 5 minutes after the beginning of experiment.

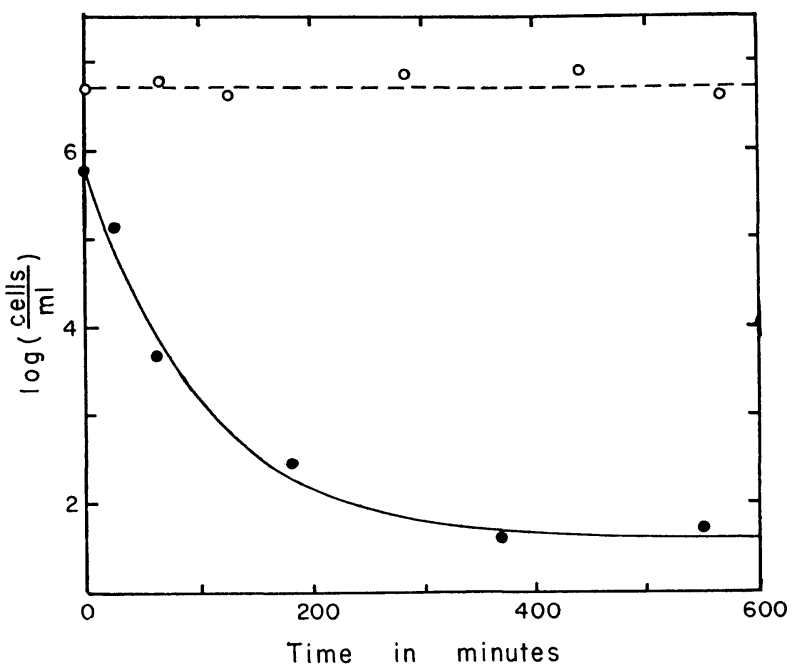

Fig. 3. Change with time of total and viable counts at $30^{\circ} \mathrm{C}$ in peptone medium.

$O=$ total count:

O=viable, count. Total count did not vary even on prolonged incubation. 
$\left.65^{\circ} \mathrm{C}\right)$, viable curves showed no lag, whereas in the upper range $\left(65^{\circ} \mathrm{C} \sim 71^{\circ} \mathrm{C}\right)$ they often showed a distinct lag. At $35^{\circ} \mathrm{C}$, both the viable and total counts did not vary within the experimental error for at least 6 hours, which indicated that, at this temperature, neither death nor growth occurred. At temperatures below $35^{\circ} \mathrm{C}$, the number of viable cells decreased. Of interest was

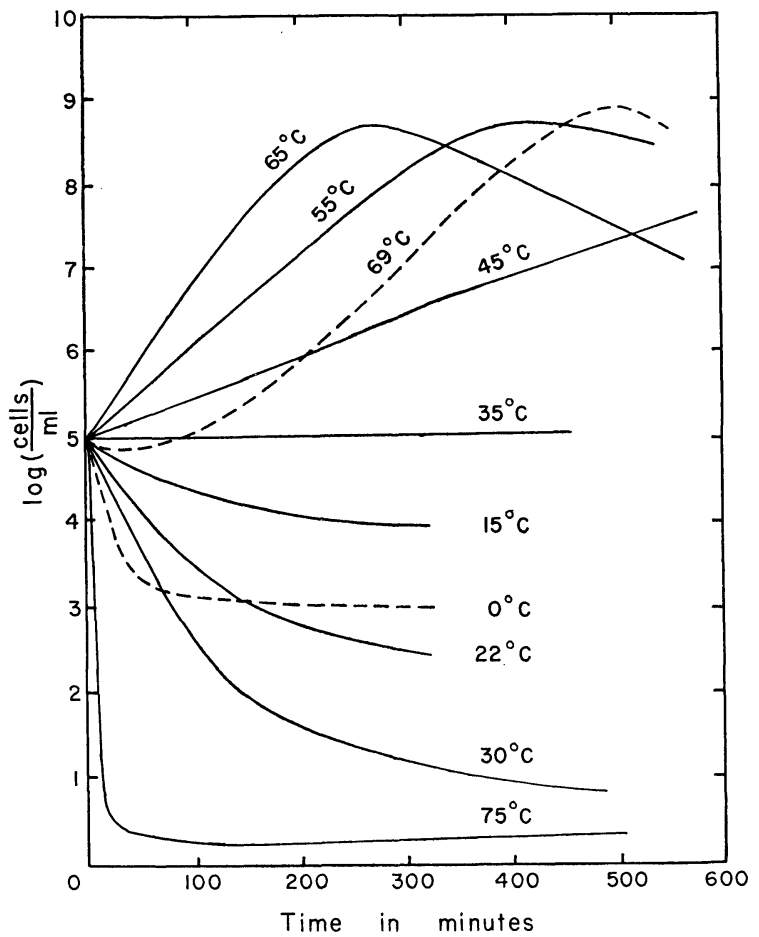

Fig. 4. Change with time of viable counts at various temperatures in peptone medium.

The initial counts in individual experiments showed some scattering around $10^{5}$ cells $/ \mathrm{ml}$. In the figure the positions of the curves were slightly shifted so as to make them start from the same point.

the fact that at $0^{\circ} \mathrm{C}$ the viable count dropped abruptly and attained an almost steady level which was higher than the final levels observed at $22^{\circ} \mathrm{C}$ or $30^{\circ} \mathrm{C}$.

From the data presented above, it may be understood that special precaution should be taken in the procedure of viable counting of this organism. The usual plating method could not be applied, since the lowering of temperature, which was necessary for solidifying the agar, caused the decrease of viable cells (cf. (4)). It was for this reason that the viable countings were conducted by a special dilution method already described. Comparative results of the ordinary and improved dilution methods are given in Table 1. 
Table 1. Comparison of the results obtained by ordinary and improved dilution methods.

\begin{tabular}{|c|c|c|c|}
\hline & $\begin{array}{l}\text { Temperature at which } \\
\text { dilution was conducted }\end{array}$ & $\begin{array}{l}\text { Method of incubating } \\
\text { diluted subcultures }\end{array}$ & $\begin{array}{l}\text { Viable count } \\
\text { calculated }\end{array}$ \\
\hline \multirow[b]{2}{*}{ Improved } & \multirow[b]{3}{*}{$\begin{array}{l}\text { Room temperature } \\
\left(15^{\circ} \mathrm{C} \sim 23^{\circ} \mathrm{C}\right)\end{array}$} & $\begin{array}{l}\text { Shaken at } 65^{\circ} \mathrm{C} \text { for } 3 \\
\text { hours (rapid method) }\end{array}$ & $2.2 \times 10^{7} \mathrm{cells} / \mathrm{m}$ \\
\hline & & $\begin{array}{l}\text { Left standing still in an } \\
\text { air thermostat at } 65^{\circ} \mathrm{C} \\
\text { for } 18 \text { hours }\end{array}$ & $3.5 \times 10^{7}$ \\
\hline Ordinary & & Same as above & ca. $10^{5}$ \\
\hline
\end{tabular}

Total number of cells in the culture was $4.3 \times 10^{7}$ cells $/ \mathrm{ml}$.

2. Effect of the Change of Temperature and Device of the "Lag

Time Method" for Determining the Viable Counts at Suboptimum Temperatures.

If a culture of the organism incubated at one temperature was trans-

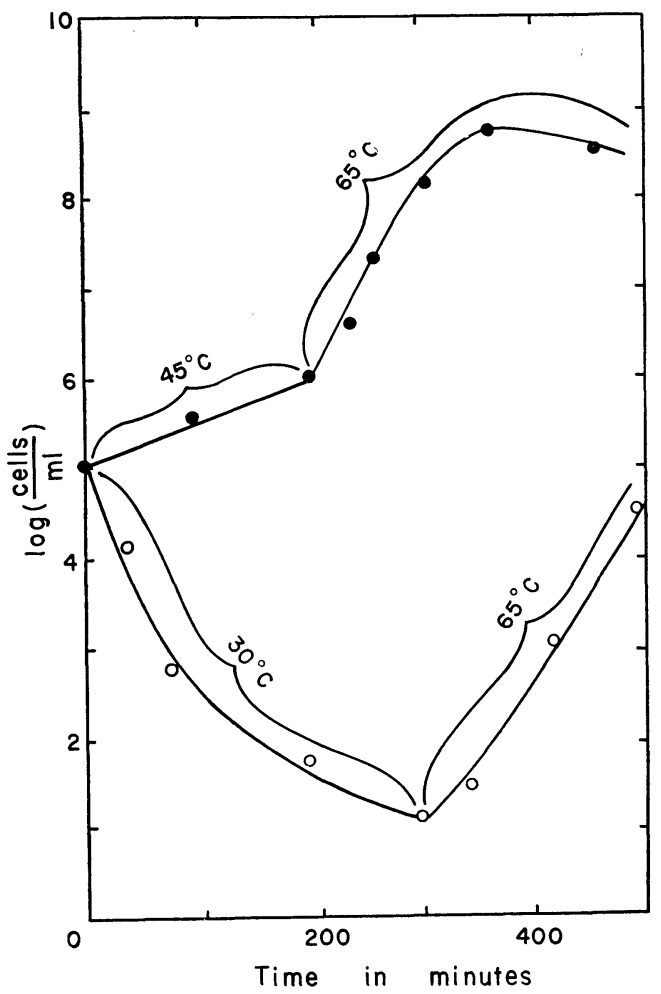

Fig. 5. Effect of temperature change upon the time-course of viable count. ferred to another temperature before it attained the population density of $10^{8}$ cells/ml or higher, it immediately assumed the growth or death characteristics at the new temperature (see Fig. 5). In the experiment reproduced by the dashed curve in Fig. 6, the change of total count (turbidity) was followed with a culture which was first incubated at $30^{\circ} \mathrm{C}$ for 4 hours, and then transferred to $65^{\circ} \mathrm{C}$ (at point A). From the figure it is apparent that the total cell number remained unchanged at $30^{\circ} \mathrm{C}$, and on transference to $65^{\circ} \mathrm{C}$ (optimal temperature) it continued to be on the same level for about 4 hours (A-B), after which it increased (B-C) with a rate which was characteristic of the time-course of increase of viable count at $65^{\circ} \mathrm{C}$. The 
solid curve drawn at the lower part of the figure shows the viable countdetermined by the dilution method-in a culture which was kept at $30^{\circ} \mathrm{C}$ throughout the course of the experiment. As may be seen from the figure,

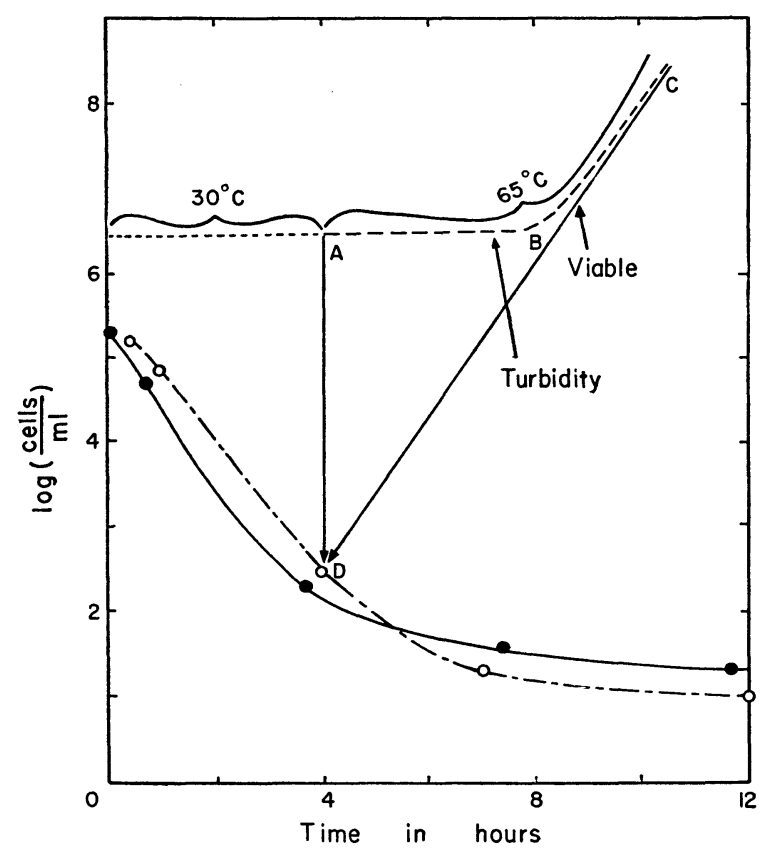

Fig. 6. Illustration of the "lag time method" for measuring the viable count.

Dashed line represents the time course of turbidity change of the culture which was first placed at $30^{\circ} \mathrm{C}$ for 4 hours and then transferred to $65^{\circ} \mathrm{C}$; broken line indecates the change with time of the viable count at $30^{\circ} \mathrm{C}$ obtained by the "lag time method"; solid curve represents the change with time of the viable count at $30^{\circ} \mathrm{C}$ obtained by the dilution method. For full explanation see the text.

the viable count at the 4 th hour of incubation at $30^{\circ} \mathrm{C}$ fell almost exactly on the point which represents intersection (D) between the vertical line from $\mathrm{A}$ and the extrapolated line from $\mathrm{B}-\mathrm{C}$ of the turbidity curve. This coincidence indicates that during the lag time $(\mathrm{A}-\mathrm{B})$ at $65^{\circ} \mathrm{C}$ there occurred a revival or positive growth - at a rate characteristic of the increase of viable cells at $65^{\circ} \mathrm{C}$-of the cells which had suffered the 4 -hour incubation at $30^{\circ} \mathrm{C}$. The broken curve in the figure was obtained by connecting the points obtained in a similar manner from the turbidity curves of the cultures which were first placed at $30^{\circ} \mathrm{C}$ for different lengths of time and then transferred to $65^{\circ} \mathrm{C}$. As may be seen, this curve coincides well with the viable curve at $30^{\circ} \mathrm{C}$ which was obtained by the dilution method. Roughly speaking, 
a one-hour difference of the lag time at $65^{\circ} \mathrm{C}$ corresponded to $10^{1}$ cells $/ \mathrm{ml}$ difference of the viable cell concentration at the time when the culture was transferred to $65^{\circ} \mathrm{C}$. In some of the experiments which will be described later, the viable counting was conducted by this "lag time method", using the technique of turbidity measurement combined with the subsequent transference of culture to $65^{\circ} \mathrm{C}$.

\section{Temperature Dependency of Respiration.}

Although the organism died at temperatures below $35^{\circ} \mathrm{C}$, its respiratory activity remained at rather high levels even below $35^{\circ} \mathrm{C}$. In Fig. 7 is shown

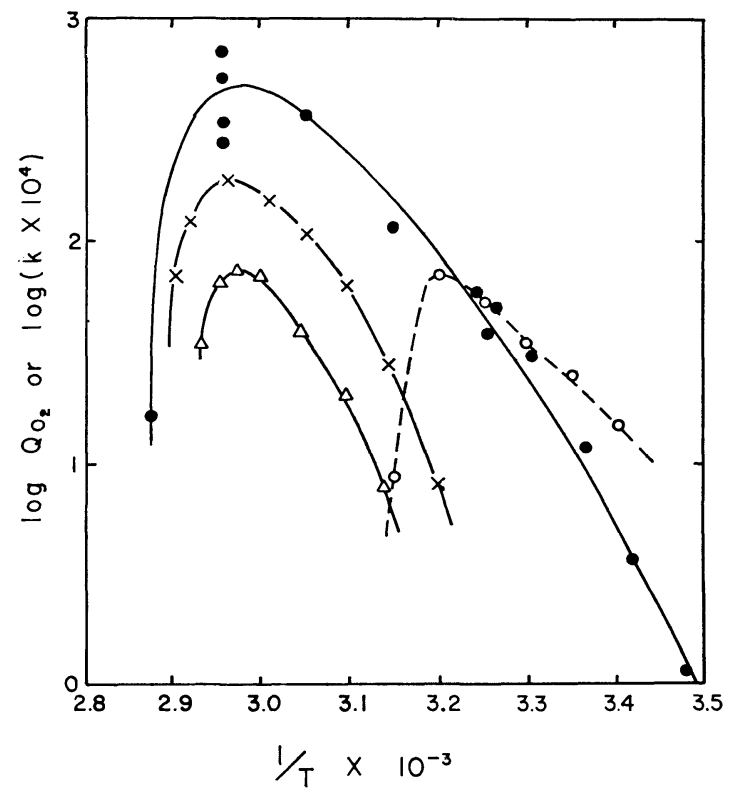

Fig. 7. Arrhenius plotting of the growth rates and the rates of oxygen consumption as they changed with temperature.

$x-\times$ : growth rate in peptone medium.

$\triangle-\triangle$ : growth rate in synthetic medium.

- $-\mathrm{Q}_{0_{2}}$ in peptone medium.

Dashed curve connecting open circles represents the growth rate of Escherichia coli measured for comparison.

the Arrhenius plotting of $\mathrm{Q}_{0_{2}}$ and the growth rate, $k$, of the organism. The growth rate, $k$, represents the increase of logarithm of cell concentration per minute at the logarithmic phase of growth. In the figure the results of growth rate measurement obtained with the peptone medium (crosses) and with the synthetic medium (trigangles) are compared with those of $\mathrm{Q}_{0_{2}}$ measurement (solid circles). It is interesting to note that the curves for growth rates and $\mathrm{Q}_{0_{2}}$ run almost parallel with each other. For comparison, temperature dependency of the growth rate of a mesophilic bacterium Escherichia coli is also shown in the figure (open circles). 


\section{Effect of "Optimal Temperature Shock" upon the Cells Dying at Low Temperatures.}

The viable cells of the organism decreased more or less rapidly when the culture was incubated at temperatures below $35^{\circ} \mathrm{C}$. During incubation at these sub-proliferative temperatures, several "shocks" with the optimal temperature, $65^{\circ} \mathrm{C}$, were given intermittently to the culture. The shock was such that the temperature of the culture attained $65^{\circ} \mathrm{C}$ for $1.0 \sim 1.5$ minutes, during which time the positive growth of cells was practically negligible. The over-all low temperature lasted for 5 hours, and during this period 1 , $4,7,9$, or 14 shocks were given at intervals of $150,60,40,30$ and 20 minutes, respectively. The effect of the shocks was measured either by the dilution method or by the "lag-time method" mentioned in the preceding section.

The results obtained are shown in Figs. 8, 9 and 10. As may be seen, the viable cells incubated at a higher temperature range $\left(10^{\circ} \mathrm{C} \sim 30^{\circ} \mathrm{C}\right)$

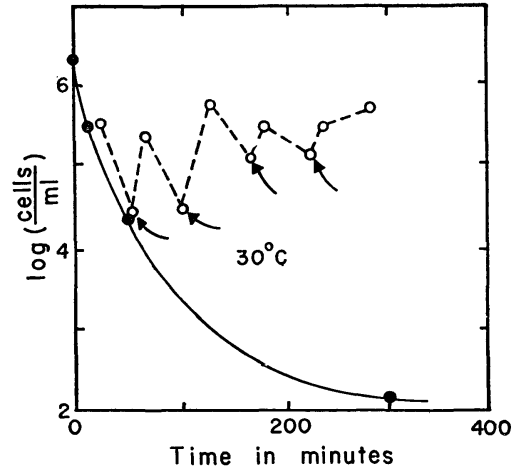

Fig. 8. Effect of $65^{\circ} \mathrm{C}$ shocks on the viable count of the culture incubated at $30^{\circ} \mathrm{C}$. (Measured by the dilution method.)

Solid line represents the time-course of the viable count of the culture which received no shock. Dashed line shows the change of the viable count brought about by the effect of shocks at $65^{\circ} \mathrm{C}$ which were given at the points indicated by the arrows.

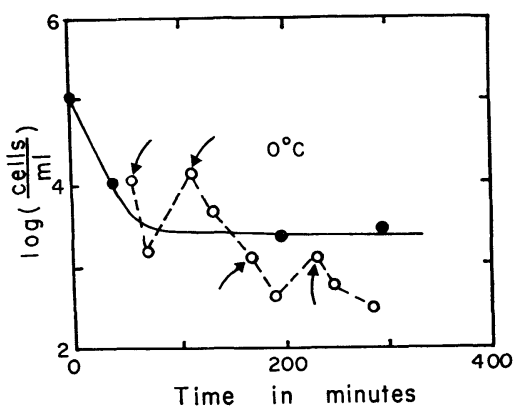

Fig. 9. Effect of $65^{\circ} \mathrm{C}$ shocks on the viable count of the culture incubated at $0^{\circ} \mathrm{C}$. (Measured by the dilution method.)

Solid line represents the time-course of the viable count of the culture which received no shock. Dashed line represents the change of the viable count brought about by the effect of $65^{\circ} \mathrm{C}$ shocks which were given at the points indicated by the arrows.

increased at each shock, while those incubated at $0^{\circ} \mathrm{C}$ decreased after each shock (see Figs. 8 and 9). In Fig. 10, the change due to the shocks of viable cell concentration occurring in 5 hours of low temperature incubation is plotted against the number of shocks given. In this plotting, the ordinate shows the relative change of the viable count, taking the viable count at the start of experiment as the zero point. On this scale, the extent of the decrease of viable count occurring in 5 hours in the control culture (without 
shock at respective temperatures) was taken as minus unity, so that the favourable and unfavourable effects of the shocks are expressed by the situation whether the curves go above or below, respectively, the level of -1.0 .

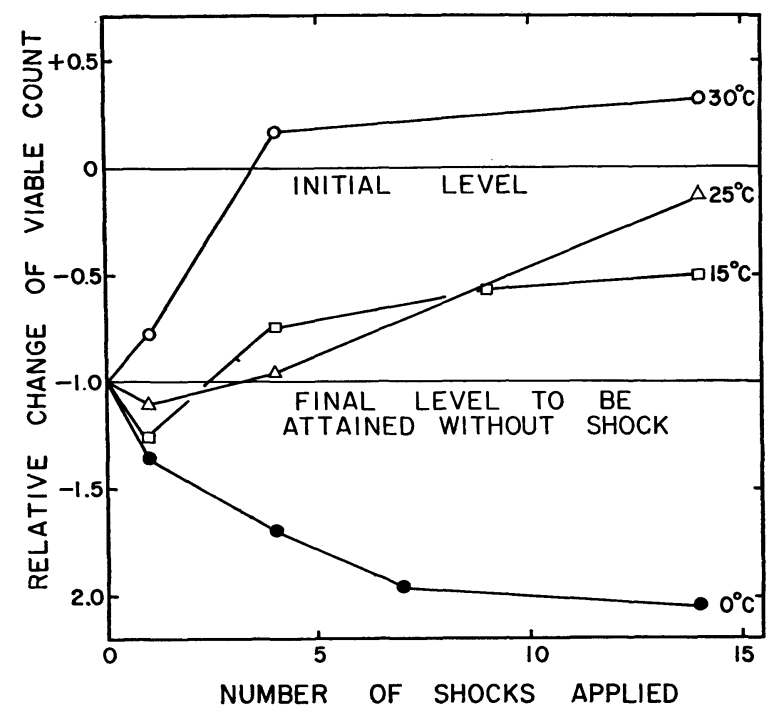

Fig. 10. Effect of $65^{\circ} \mathrm{C}$ shocks on the change of viable cell concentration during the low temperature incubation.

The ordinate is the difference of viable cell concentration which was measured by taking as unity the drop of the viable count of the culture incubated at each low temperature for 5 hours but not treated with " $65^{\circ} \mathrm{C}$ shocks". The zero-level represents the viable count just in advance of the low temperature incubation; level -1.0 represents the viable count after low temperature incubation with no shock. Two different types of the effect are clearly observed. Viable cell concentrations were measured by the "lag time method".

As is apparent from the figure, there are two different types of response to the $65^{\circ} \mathrm{C}$ shock, depending upon the basic temperature of incubation. It is interesting to note that the change of the type of response occurred in the temperature range, where the change of the type of decaying took place (see Fig. 4).

\section{DISCUSSION}

The rapid decrease of viable cells at temperatures above $75^{\circ} \mathrm{C}$ may conceivably be due to the lethal effect of heat in an ordinary interpretation. The finding that the proliferative behaviour of the organism is essentially 
different at temperatures above and below $35^{\circ} \mathrm{C}$ seems to have a significance in comprehension of the thermophilic physiology of this organism. As shown in our experiment, the organism died more or less rapidly at temperatures below $35^{\circ} \mathrm{C}$, while its respiratory activity remained at appreciably high levels at those temperatures. Presumably, there occured at those temperatures some unbalancing between the energy-yielding process and the life-maintaining (or synthetic) process, which might have been a cause of the decaying of cells at those temperatures. Of interest in this connection is the observation reported by Campbell and Williams $(6,7)$ that a certain thermophilic bacterium showed different nutritional requirements or different patterns of cell metabolism at higher and lower temperatures.

Thermophilic bacteria are known to display a rapid and explosive growth in natural and industrial conditions caused by some change of environmental conditions which has thus far been left unelucidated in clear terms $(4,5)$. It may be reasonable to suppose that the striking effect of "optimal temperature shocks" upon the increase of viable count of the organism may play some part in this phenomenon. In fact, the cultures of our experimental organism exhibited an explosive increase in turbidity during the first five minutes or so, when the culture kept at $30^{\circ} \mathrm{C}$ was transferred to $65^{\circ} \mathrm{C}$ after it had been intermittently exposed to shocks at $65^{\circ} \mathrm{C}$.

It seems to the writers that further investigations on the characteristic phenomena occurring on transference of the organism to different temperatures would provide an important clue to the elucidation of the nature of thermophilism.

\section{SUMMARY}

1) Using a thermophilic bacterium isolated from compost, new and reliable methods for determining the exact viable count of the organism were developed. By using these methods, systematic studies were made on the viability and growth of the bacterial cells at different temperatures as well as their responses to the change of temperature.

2) It was observed that the organism grew at temperatures between $35^{\circ} \mathrm{C}$ and $72^{\circ} \mathrm{C}$ (optimum at $65^{\circ} \mathrm{C}$ ), and died instantly at temperatures above $75^{\circ} \mathrm{C}$, and gradually at those below $35^{\circ} \mathrm{C}$. In the lower lethal range $\left(10^{\circ} \mathrm{C} \sim\right.$ $30^{\circ} \mathrm{C}$ ) bacterial viability was found to be increased by the application of an optimal temperature $\left(65^{\circ} \mathrm{C}\right)$ " shock", lasting only for a short period $(1.0 \sim 1.5$ minutes).

3) The importance of these phenomena for comprehension of the mechanism of thermophilic nature of temperature-tolerant organisms was discussed 


\section{ACKNOWLEDGEMENT}

The writers wish to express their heartfelt gratitude to Professor $\mathrm{H}$. Tamiya, Tokyo University, for his guidance and encouragement throughout this investigation.

\section{REFERENCES}

(1) Allen, M. B.: J. Gen. Physiol., 33, 205, 1950.

(2) McCrady, M. H.: Cand. Publ. Hlich. J., 9, 201, 1918.

(3) Marsh, C. and W. Militzer: Arch. Biochem. Biophys,, 36, 269, 1952.

(4) Allen, M. B.: Bacteriol. Revs., 17, 125, 1953.

(5) Forsyth, W. G. C. and D. W. Webley: Proc. Soc. Appl. Bacteriol., 1948, 34, 1948.

(6) Campbell, L. L., Jr. and O. B. Williams: J. Bacieriol., 65, 141, 1953.

(7) CAMPBell, L. L., Jr. and O. B. Williams: J. Bacteriol., 65, 146, 1953. 